\title{
Relationship of Group Dynamics and Fishermen Independence in Fisheries Agribusiness Attaining Maximum Sustainable Yield
}

\author{
Hamdi Rosyidi1,*, Jabal Tarik Ibrahim ${ }^{2}$, Sutawi Sutawi ${ }^{3}$, Olga Anne $^{4}$, and \\ Diana Rachmawati ${ }^{5}$ \\ ${ }^{1}$ Master's Degree, Department of Agriculture Science, Postgraduate Program, \\ University of Muhammadiyah Malang, J1. Raya Tlogomas No. 246, \\ Malang 65145, East Java, Indonesia \\ ${ }^{2}$ Department of Agribusiness, Faculty of Agriculture and Animal Sciences, \\ University of Muhammadiyah Malang \\ ${ }^{3}$ Department of Animal Sciences, Faculty of Agriculture and Animal Sciences, \\ University of Muhammadiyah Malang \\ ${ }^{4}$ Department of Natural Sciences, Faculty of Marine Technology and Natural Sciences of \\ Klaipeda University, H. Manto g. 84, Klaipeda 92294, Lithuania \\ ${ }^{5}$ Department of Aquaculture, Faculty of Fisheries and Marine Sciences, Diponegoro University, \\ Jl. Prof. Soedarto, SH, Tembalang, Semarang 50275, Central Java, Indonesia
}

\begin{abstract}
This study aimed to examine the factors and the influence of group dynamics and the independence of fishing group members in catch fisheries agribusiness activities. This research was carried out using a survey method in the Rukun Nelayan Blimbing in Paciran District, Lamongan Regency, East Java Province, Indonesia from February to March 2019. The result showed the group dynamics and independence of fishermen in catch fisheries was high, but group dynamics did not influence the independence of fishermen in catching fisheries agribusiness. The factors that influence group dynamics were structuring, coaching and development, atmosphere, effectiveness. The factors affected the independence of the group were the addition of production facilities, prices, market, and fishermen. Those factors are needed to attain the good management in maximum sustainable yield (MSY).
\end{abstract}

Keywords: Development fisheries sector, fishermenhood, increase welfare, social interaction, sustainability

\section{Introduction}

Indonesia is an archipelagic country with an abundant landscape of marine wealth. In its theoretical study, Lasabuda states that Indonesia has been recognized internationally through UNCLOS 1982 that the total area of Indonesia's sea area reaches $5900000 \mathrm{~km}^{2}$

\footnotetext{
* Corresponding author: hamdiorzams@gmail.com
} 
[1]. International recognition was later ratified by Indonesia in Law No. 17 of 1985. There are $3200000 \mathrm{~km}^{2}$ of territorial waters that connect the entire archipelago. This condition makes Indonesia the largest archipelago country in the world.

PPN-Pelabuhan Perikanan Nusantara [Archipelago Fisheries Port] of Brondong Lamongan is the largest docked fisheries base in the northern region of East Java Province, Indonesia whose production reaches an average of 100 ton $\mathrm{d}^{-1}$. PPN Brondong activities involved 12160 fishermen, 21695 fishing gear, 1385 motorboats, 312 traders/distributors and 170 fish processors. The north sea of the island of Java has various types of fish both pelagic and demersal. The fishing areas in Brondong District are in 712 Fisheries Management Areas (WPP 712) covering the areas of Masalembu, Matasiri, Kramean, and around Bawean, Indonesia.

The fisheries sector has a major role to play at the level of PAD- Pendapatan Asli Daerah [Local Government Revenue] of Lamongan Regency, Indonesia. Data Distribution of Percentage PDRB- Produk Dosmetik Regional Bruto [Gross Regional Domestic Product] of the fisheries sector in Lamongan Regency reached $17.49 \%$, outperforming the food crop sector contributed $13.09 \%$ [2]. While the contribution of the fisheries sub-sector to the agriculture, forestry and fisheries sector in Lamongan in 2016 reached $44.39 \%$ [3].

BPS-Badan Pusat Statistik Lamongan mentioned that the capture fisheries activities in 2015 employed 17892 workers, then increased $6.36 \%$ up to 19030 in 2016 [2]. The large number of workers in the fisheries sector makes the emergence of fellow fishermen community groups to help each other solve common problems.

The fisheries sector can be developed through a group approach. Triwahyuni mentioned the development of dairy goat businesses driven by the role of livestock farmer groups to increase added value and efficient management [4]. Farmers can interact with one another in their group to increase knowledge and ability to manage agribusiness systems. Sondakh mentioned that social interaction of fishermen groups is the key to success and organizational goals undertaken by members consciously to build interaction between fellow members and administrators of fishing groups [5].

Research aims to determine the level of group dynamics, level of independence and the relationship between the two variables in the fishermen group in terms of catch fisheries agribusiness. Research provides an overview related to group dynamics and the independence of fishermen in catch fisheries agribusiness as scientific development material.

\section{Methods}

The group approach to fishermen is carried out through the RN- Rukun Nelayan (fishermenhood/Community Association). The study was conducted on RN Blimbing. RN Blimbing is one of the $17 \mathrm{RN}$ in Lamongan Regency, Indonesia. RN Blimbing consists of 5321 fishermen who work on 410 ships operating in the Java Sea. This research was conducted using a quantitative survey method. That aimed to explain the relationship between variables (explanatory). The sampling used simple random sampling. The indicator of group dynamic i.e. group goals, structure, function and task, coaching and development, compactness, atmosphere, pressure, effectiveness, hidden agenda, group dynamic. The research instrument has been declared valid and reliable in the test of validity and reliability. Research data have also been tested for normality, linearity, and homogeneity, then proceed to path analysis. 


\section{Results and discussions}

\subsection{Level of group dynamics}

Table 1. Results of indicators assessment of group dynamics (\%)

\begin{tabular}{|l|c|c|c|c|}
\hline \multicolumn{1}{|c|}{ Indicator } & Low & Medium & High & Very high \\
\hline Group goals & 22.22 & 37.78 & 28.89 & 11.11 \\
\hline Structure & 4.44 & 24.44 & 46.67 & 24.44 \\
\hline Function and tasks & 11.11 & 22.22 & 37.78 & 28.89 \\
\hline Coaching and development & 8.89 & 17.78 & 48.89 & 24.44 \\
\hline Compactness & 15.56 & 20.00 & 26.67 & 37.78 \\
\hline Atmosphere & 11.11 & 37.78 & 42.22 & 8.89 \\
\hline Pressure & 24.44 & 40.00 & 28.89 & 6.67 \\
\hline Effectiveness & 17.78 & 28.89 & 40.00 & 13.33 \\
\hline Hidden Agenda & 15.56 & 37.78 & 26.67 & 20.00 \\
\hline
\end{tabular}

Based on Table 1, group dynamics were in the high category as well as the supporting indicators structure such as functions and tasks, coaching and development, group atmosphere and effectiveness and cohesiveness. As for the group goals, the pressure and hidden intent were in the medium category. This result indicated that RN Blimbing has group activities that always accommodate the interaction between its members so that it brings up dynamics. Febriani et al. states that dynamics implied the interaction and interdependence between members in own group and other groups [6].

Groups make positive contributions to the organization such as creating collaboration between group members, build effective communication, increase job satisfaction and motivation, and a culture of competition. On the other hand, conflict can have negative impacts such as decline poor productivity and competition. To prevent it, organization need to be aware of group functions, group dynamics, individual boundaries, as well correct communication methods and techniques [7].

Based on their work activities, the fishing profession has social and economic stratification. Resilience status of ship owners as a means of livelihood has the strongest position, followed by the captain and the weakest, namely ABK [8]. Zain et al. revealed that the low quality of life of fishermen is caused by competition between fishermen. Fishermen can compete with each other for big profits [9].

The higher resilience of certain groups in fishing communities contributes to increased social differentiation, which in turn undermines community resilience. Resilience at the individual, household and group level will encourage persistence, adaptability, and the ability to transform in work so as to encourage complementarity, not conflict [10]. In this case, fishermen groups have a strategic position to suppress socio-economic differentiation and build a spirit of cooperation and collaboration for the welfare of all fishermen members.

In addition, Blimbing RN also has an open relationship with members outside groups such as the government in the fisheries sector. This interaction is more responsive and critical in responding to issues outside the group and becomes a conversation within the group. Social interaction carried out by fishermen can be a strength in achieving group goals together. Communication with related local governments has a strategic role and even has an impact on fishermen's income. Moento, et al. states that the Merauke Regency 
Fisheries Department plays a role in increasing the income of the fishing community in Pelita Samkai Village [11].

Sondakh et al. states that social interaction of fishermen groups is the key to success and organizational goals are carried out on the awareness of members to consciously establish communication or interaction between one another, between members and management of fishermen groups [5]. Squires et al. adding aspects of social and institutional sustainability can be seen from how group members resolve conflicts and continue to work together [12]. Conversely, social exclusion influences interest and affiliation behavior in the group [13].

Fishermen of RN Blimbing on average go fishing for $1 \mathrm{wk}$ to $3 \mathrm{wk}$. This potent to become an obstacle for the group in carrying out activities to gather whole members. Group member interactions have problems such as no free time because the members have to go fishing [14]. By high dynamics, the management and members of the Blimbing RN have had the right strategy in dealing with these problems. They utilize free time to carry out group activities when bad weather, so that the majority of members can be involved.

\subsection{Level of fishermen independence}

Table 2. Result of indicators assessment of fishermen independence (\%)

\begin{tabular}{|l|c|c|c|c|}
\hline \multicolumn{1}{|c|}{ Indicators } & Low & Medium & High & Very high \\
\hline $\begin{array}{l}\text { Independence determines the } \\
\text { catching area }\end{array}$ & 22.22 & 37.78 & 28.89 & 11.11 \\
\hline $\begin{array}{l}\text { Independence determines the } \\
\text { addition of production facilities }\end{array}$ & 4.44 & 24.44 & 46.67 & 24.44 \\
\hline Independence determines prices & 11.11 & 22.22 & 37.78 & 28.89 \\
\hline Independence of market & 8.89 & 17.78 & 48.89 & 24.44 \\
\hline $\begin{array}{l}\text { Independence in occupational } \\
\text { health and safety }\end{array}$ & 15.56 & 20.00 & 26.67 & 37.78 \\
\hline Independence of fishermen & 11.11 & 37.78 & 42.22 & 8.89 \\
\hline
\end{tabular}

The fishermen's independence reached a high category $42 \%$. Indicators of independence that are in the high category are the means of production, pricing, marketing, and occupational health and safety in the very high category. The independence in determining the area of capture is in the medium category.

The high level of independence illustrates that so far fishermen have been able to face their own problems so that they do not have excessive dependence on other parties' assistance. Government assistance was not a priority for fishermen to keep running their fishing activities. Fishermen become resilient due to the pressure of the necessities of life that requires them to continue to exist and survive in their work.

In India, fishermen groups are said to have a role in increasing the maximum yield from fishery resources so as to increase the income and welfare of their members [15]. Education or learning in fishing group activities can improve the socio-economic status of fishermen. Basavakumar et al. states that the socio-economic status of fishing communities can be 
improved by providing education such as the application of better fishing methods [16]. Good fishing methods can improve the quality of fish caught. Fish quality is a factor that has a significant effect on fish prices [17].

Richmon et al. explained that the framework for the sustainability of fishing communities includes four categories, namely economy and markets; social and community; physical infrastructure and critical services; environment and regulation. The sustainability of this category is very important for the long-term survival of fishing communities and strategic plans to encourage improvement, expansion, or investment in all areas. Each category is connected and dependent on each other in the fishing community [18].

A well-managed fishing group can encourage professional investment collaborations. Additional capital for investment and operational costs will encourage participation and institutional strengthening. Group members have the values of helping each other, caring, open communication, and collaboration in groups. They develop mutual understanding and can manage conflict peacefully [19].

\section{Conclusion}

The results of this study are taken into consideration and become input in developing and fostering fishermen groups. As an effort to optimize the potential of fishermen groups in conducting capture fisheries agribusiness activities, especially in Lamongan Regency, East Java Province, Indonesia. Both the group dynamics and independence of fishermen in catch fisheries was high, but group dynamics did not influence the independence of fishermen in catching fisheries agribusiness. The factors that influence group dynamics were structuring, coaching and development, atmosphere, effectiveness. The factors affected the independence of the group were the addition of production facilities, prices, market, and fishermen. Those factors are needed to attain the good management in maximum sustainable yield (MSY).

\section{References}

1. R. Lasabuda. JIP. 1, 2:92-101(2013). [in Bahasa Indonesia]. https://ejournal.unsrat.ac.id/index.php/platax/article/view/1251

2. Badan Pusat Statistik Kabupaten Lamongan, Distribusi Persentase Produk Domestik Regional Bruto Kabupaten Lamongan Atas Dasar Harga Konstan 2010-2016 [Distribution of Percentage of Gross Regional Domestic Product in Lamongan Regency on the basis of Constant Price 2010-2016] [Online] from https://lamongankab.bps.go.id/statictable/2017/07/04/671/distribusi-persentaseproduk-domestik-regional-bruto-lamongan-atas-dasar-harga-konstan-2010-2016.html (2019).p.1. [Acessed on 20 May 2019). [in Bahasa Indonesia]

3. Badan Pusat Statistik Kabupaten Lamongan. Produk Domestik Regional Bruto Kabupaten Lamongan Menurut Lapangan Usaha 2013-2017 [Lamongan Regency Gross Regional Domestic Product by Business Field 2013-2017] [Online] from https://lamongankab.bps.go.id/publication/2018/08/15/e37aa39888d81f987e570e32/pr oduk-domestik-regional-bruto-kabupaten-lamongan-menurut-lapangan-usaha-20132017.html (2017).p.109. [in Bahasa Indonesia] 
4. A. Triwahyuni, M. Sulistyati, L. Nurlina, Students e-Journals. 5,3:1-9(2016). [in Bahasa Indonesia].

http://jurnal.unpad.ac.id/ejournal/article/view/9623

5. V. B. Sondakh, J. A. Andaki, M. P. Wasak, J. Akulturasi, 5,9:589-602(2017). [in Bahasa Indonesia].

https://ejournal.unsrat.ac.id/index.php/akulturasi/article/view/16984

6. E. M. Febriani, Saharudin, J. Sosiol. Pedesaan, 2,1:17-29(2014).[in Bahasa Indonesia].

https://journal.ipb.ac.id/index.php/sodality/article/download/9409/7373

7. H. Gençer, Univers. J. Educ. Res. 7,1:223-229(2019).

https://www.researchgate.net/publication/331482821_Group_Dynamics_and_Behavio ur

8. B. Vatria, B. Wiryawan, E. S. Wiyono, M. S. Baskoro, AACL Bioflux, 12,1:310319(2019).

http://www.bioflux.com.ro/docs/2019.310-319.pdf

9. R. M. Zain, M. K. A. Kamarudin, M. H. M. Saad. Int. J. Acad. Res. Bus. Soc. Sci., 8,10:640-650(2018).

https://hrmars.com/papers_submitted/4770/Assessment_of_Quality_of_Life_on_Fishe rmen_Community_in_Kuala_Terengganu, Malaysia_A_Review.pdf

10. M. Leite, H. Ross, F. Berkes. Ecol. Soc. 24,3:1-13(2019). https://www.jstor.org/stable/26796970?seq=1\#metadata_info_tab_contents

11. P. A. Moento, A. P. Yusuf, A. F. Adam, E. E. Maturbongs, A. P. Tljlien, M. Yunus. IOP Conference Series: Earth and Environmental Science. 473:1-7(2019). https://iopscience.iop.org/article/10.1088/1755-1315/473/1/012033/pdf

12. K. Squires, M. G. Wiber. Ecol. Soc., 23,2:1-12(2018). https://www.ecologyandsociety.org/vol23/iss2/art25/ES-201810137.pdf $+\& \mathrm{~cd}=12 \& \mathrm{hl}=\mathrm{id} \& \mathrm{ct}=\mathrm{clnk} \& \mathrm{gl}=\mathrm{id}$

13. D. F. Sacco, M. J. Bernstein, Am. Psychol. Assoc. 19,4:211-224(2015). https://www.apa.org/pubs/journals/features/gdn-gdn0000035.pdf

14. D. K. Kusnani, P. Muljono, A. Saleh, J. Penyuluhan, 11,2:129-142(2015). [in Bahasa Indonesia]. https://journal.ipb.ac.id/index.php/jupe/article/view/10578

15. L. K. Tyagi, A. S. Bisht, A. Pal, K. K. Lal. J. Community Mobilization Sustain. Dev., 8,1:90-93(2013).

https://krishi.icar.gov.in/jspui/bitstream/123456789/4749/1/Functioning\%20of\%20fis hing\%20cooperative\%20societies\%20paper.pdf

16. K. V. Basavakumar, S. Devendrappa, S. T. Srenivas. J. Agric. Sci.

24,5:684-687( 2011).

https://www.researchgate.net/publication/266458070_A_study_on_profile_of_fishing _community_of_a_village_in_Karnataka/link/556c31fc08aefcb861d62277/download

17. M. P. Alapan, E. L. I. Arpilleda, K. J. R. Altizo, G. K. R. Frias, J. D. Ravelo. J.

Environ. Ecol. 7,2:34-41(2016).

https://www.researchgate.net/publication/312237781_Factors_Affecting_the_Market

Price_of_Fish_in_the_Northern_Part_of_Surigao_Del_Sur_Philippines

18. L. Richmond, R Cumoucel, H. Pontarelli, L. Casali, W. Smith, K. Gillick, et al. Sustain. 11,7:1-22(2019).

https://ideas.repec.org/a/gam/jsusta/v11y2019i7p1904-d218457.html

19. H. Saediman, F. F. Syah, T. La Ola, M. Tufaila, Bahari, L. Daud, J. Humanit. Soc.

Sci. 24,8:5-12(2019).

http://www.iosrjournals.org/iosr-jhss/papers/Vol.\%2024\%20Issue8/Series-

6/B2408060512.pdf 